\title{
BATISMO DE SANGUE: LITERATURA TESTEMUNHAL COMO FERRAMENTA DO RECONHECIMENTO HISTÓRICO DA DOR
}

\author{
Marta Gouveia de Oliveira Rovai ${ }^{1}$ \\ Eduardo Augusto Carvalho Teixeira ${ }^{2}$
}

\begin{abstract}
Resumo: Este artigo discute e busca compreender a literatura de testemunho como fonte histórica importante para o entendimento da ditadura civil-militar e do processo de redemocratização no Brasil, por meio da obra do Frei Carlos Alberto Libânio Christo, o Frei Betto, intitulada Batismo de Sangue e publicada em 1982. Entende-se que as produções testemunhais de sobreviventes de grandes catástrofes não são reflexos da realidade, mas produtos históricos de uma sociedade específica e de agentes discursivos que interferem no próprio processo histórico, como o gênero testemunhal. A adoção de perspectivas e linguagens diferenciadas sobre a leitura do passado, o possível choque de conteúdos e interpretações entre a memória coletiva de militância de grupos distintos e a construção da memória relativa à participação de setores da Igreja Católica na resistência armada ao regime militar são preocupações abordadas neste texto.
\end{abstract}

Palavras chave: Batismo de Sangue; Ditadura; Literatura; Testemunho; Dominicanos.

Abstract: This article discusses and seeks the comprehension of witness testimony as an important historical source to understand the civil-militar dictatorship and the process of democratization of Brazil, through the literary work of the priest Carlos Alberto Libânio Christo, Frei Betto, called Batismo de Sangue, published in 1982. It is understood that the testimonial productions of survivors of great catastrophes, aren't the reflexes of reality, but the historical products of a specific society and of discursive agents that interfere in the historical process itself, as a testimonial gender. The choice of perspectives and different languages about the analysis of the past, the possible shock of interpretations and contents between the collective memory of militancy of different groups and the construction of relative memory to the participation of sectors of the Catholic Church in the armed resistence to the military regime are some of the concerns addressed in this article.

Keywords: Batismo de Sangue; Dictatorship; Literaty; Testimony; Dominicanos.

\footnotetext{
${ }^{1}$ Doutora pela Universidade de São Paulo (USP); Professora Adjunta da Universidade Federal de Alfenas (UNIFAL/MG); Pós Doutoranda pela UFF; líder do Grupo de Pesquisa História do Brasil: memória, cultura e patrimônio; pesquisadora do Núcleo de Estudos em História Oral (NEHO/USP). E-mail: martarovai@usp.br

${ }^{2}$ Aluno concluinte de Graduação de História na Universidade Federal de Alfenas; membro do grupo de pesquisa História do Brasil: memória, cultura e patrimônio; pesquisador de Iniciação Científica sobre as relações entre literatura e história, pela FAPEMIG. E-mail: eduardoaugusto49@gmail.com
} 


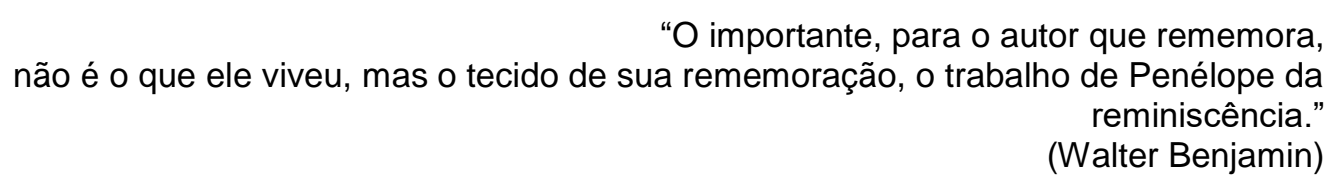

\section{Introdução}

A História Cultural (ou Nova História Cultural), a partir dos Annales, promoveu o debate em torno da ampliação de temas, objetos e fontes para a História, ampliando o diálogo com outras áreas do conhecimento, inclusive a Literatura. A partir disso, passou-se a entender esta última como uma fonte documental e uma forma de acesso ao universo sociocultural de determinado tempo histórico. Este artigo, em especial, pretende mostrar a obra Batismo de Sangue como um possível cruzamento entre os diferentes caminhos que a pesquisa historiográfica e a produção literária podem realizar, por meio do conceito de testemunho, demonstrando que a narrativa do autor Carlos Alberto Libâneo Christo, o Frei Betto, não só fornece informações históricas obre o período ditatorial brasileiro (1964/1984), como também revela e denuncia o que muitas vezes só a obra literária consegue representar: as feridas subjetivas que, neste caso, são traumas coletivos e históricos.

Pretendemos discutir o valor da chamada literatura testemunhal, fortemente aliada da História, numa tentativa, muitas vezes, de cumprir o papel de "escovar a História a contrapelo", como afirmava Walter Benjamin (1993, p.225). Apresentamos a obra de Frei Betto para tentar mostrar como é possível trazer, pela memória (no caso a escrita), versões que conflitem e expressem olhares e entendimentos de grupos perseguidos e silenciados pelas arbitrariedades do Estado autoritário, como foi o caso da guerrilha e dos frades dominicanos, objetos da narrativa do autor.

Em tempos de transição democrática ou de justiça de transição ${ }^{3}$ cabe apontar para esta obra como uma das pioneiras na denúncia contra a violência cometida contra aqueles que se opuseram ao regime, entre 1964 e 1984. Contra o processo de "esquecimento forçado", desejado por perpetradores e

\footnotetext{
${ }^{3}$ Justiça de Transição ou Justiça Transicional, segundo Esteban Cuya, seria o "conjunto de medidas direcionadas a superar os graves danos causados à sociedade por regimes totalitários e/ou ditatoriais que, em contextos de anomalia constitucional, cometem violações aos direitos humanos contra pessoas ou grupos de uma determinada nação" (2011, p. 40). São seus componentes básicos a justiça, a verdade, as reformas políticas e a reparação aos danos.
}

Revista Eletrônica Literatura e Autoritarismo: Narrativa Testemunhal e Relações Históricas - ISSN 1679-849X |67| http://cascavel.ufsm.br/revistas/ojs-2.2.2/index.php/LA/index 
promovido a partir da Lei da Anistia, de 1979, a narrativa e o testemunho de Frei Betto tornam-se um instrumento valioso para a História.

\section{As relações entre história e literatura}

A literatura é capaz de representar um fato, partindo de um contexto histórico e de um real que pretende dizer, mas que nem sempre consegue ser entendido. Mais do que o papel ficcional, ela está em constate diálogo com a História e pode nos falar sobre aquilo que foi silenciado, esquecido e ocultado. Trata-se aqui, principalmente, de nos referirmos às versões oficiais relacionadas às experiências traumáticas que configuraram um passado coletivo e histórico doloroso, como foram as ditaduras militares latinoamericanas, e sobre as quais as narrativas testemunhais têm valor de mediação e publicização:

O mundo precisa de narrativas - sejam estas as narrativas históricas, baseadas ou inspiradas em um vivido que deixou suas marcas através das fontes históricas, sejam as narrativas literárias, a princípio geradas pela criatividade livre de um autor, mas na verdade oriundas de relações que se dão na própria vida e através das próprias estruturas básicas do viver, portanto através da própria história. (BARROS, 2010, p. 9)

A ideia de uma "verdade literária" como uma fonte se explica na medida em que entendemos que a representação do imaginário social é tão "real" quanto os acontecimentos e que as narrativas configuram-se, também, como fatos em si, reveladores de desejos, medos e perspectivas futuras. $\mathrm{Na}$ literatura, as temporalidades da história se cruzam, entre a experiência e a espera, o vivido e o imaginado. Ela não é independente dos acontecimentos sociais, pois mesmo quando ficcional está em constante relação e interlocução com o contexto na qual está inserida. Segundo Sandra Jatahy Pesavento, "para o historiador a literatura continua a ser um documento ou fonte, mas o que há para ler nela é a representação que ela comporta [...] o que nela se resgata é a reapresentação do mundo que comporta a forma narrativa" (PESAVENTO, 1995, p. 117). 
Nesse sentido, as fontes de literatura testemunhal são privilegiadas, na medida em que mostram eventos e vidas de personagens, inseridos numa realidade $e$, mais do que, apontam problemas que percorrem as temporalidades cruzadas, tocam em feridas abertas e tornam a memória uma forma de redenção do passado silenciado. Colocam em questão angústias ainda presentes, como aquelas relacionadas à tortura e à violação dos direitos humanos. Nesse sentido, o que importa na leitura e análise de obras como o perfil de Batismo de Sangue não é somente seu valor documental enquanto autenticidade do fato, mas o seu testemunho, sua posição baseada nas experiências, nos sentidos, no compartilhamento de dores esquecidas, sem querer dar conta da história ou de esgotar a verdade, pois o testemunho se assume como um recorte, um olhar, a partir de onde o autor esteve e está.

Como afirma Jaime Ginzburg (2012), não é debate consensual o conceito de testemunho, mas ele se estende em torno da escrita sobre 0 trauma e a exclusão/vitimização. $O$ interesse pelo testemunho está relacionado ao comprometimento com a publicização da memória individual e coletiva e com a responsabilidade social em torno de um passado traumático, mesmo quando as narrativas são individuais. Sobre a origem deste gênero da literatura, afirma Jaime Ginzburg:

Encontramos a acepção literatura de testemunho em estudos dedicados a Primo Levi, referentes à Segunda Guerra Mundial. O termo foi apropriado pelos estudos latino-americanos, com referências a autores como Rigoberta Menchú e, recentemente, a expressão carcerária, em Luiz Alberto Mendes e André Du Rap. Falamos em testemunho também para referir à escrita de resistência à colonização na África, como no caso de Pepetela. (GINZBURG, 2012, p. 52)

Cada vez mais na América Latina e, em especial no Brasil, a literatura de testemunho tem ganhado espaço na reflexão sobre as experiências vivenciadas nos regimes autoritários, entre os anos 1960 e 1980, denunciando as arbitrariedades e abusos cometidos pelo Estado e seus efeitos sobre as subjetividades, em solidariedade aos que sofreram e numa relação de atenção crítica à permanência da violência. Não se trata, nesse sentido, de entender a literatura separadamente da história, opondo ficção e fato, mas de entender a escrita como um problema ético, comprometido com o respeito aos direitos

Revista Eletrônica Literatura e Autoritarismo: Narrativa Testemunhal e Relações Históricas - ISSN 1679-849X |69| http://cascavel.ufsm.br/revistas/ojs-2.2.2/index.php/LA/index 
humanos e como uma posição do autor no campo social de conflitos e disputas pela memória, contra o discurso de um Estado violador e perpetrador e contra a permanência constante de ameaça à integridade humana.

A literatura testemunhal exige uma postura não mais ligada ao entretenimento e ao lúdico, mas à denúncia do sofrimento, da exclusão e da perpetração, que produziram sequelas permanentes e que são ignoradas pelo desconhecimento e pela apatia social, na atualidade. Não se trata de colocar à prova os fatos narrados por Frei Betto, em sua obra Batismo de Sangue, mas entendê-la enquanto esforço de enunciação e reflexão sobre traumas, uma forma de elaboração de algo indizível ou quase impronunciável, até mesmo incompreendido em sua dimensão traumática para o leitor.

Como afirma Márcio Seligmann-Silva, a literatura testemunhal seria a forma de romper com a "outridade", ou seja, dissolver a ponte da indiferença diante da possibilidade da violência, do apagamento e da morte em vida a que muitos foram condenados por não encontrarem espaço para dizer. A literatura pode representar o caminho em que "narrar o trauma, portanto, tem em primeiro lugar este sentido primário de desejo de renascer" (SELIGMANNSILVA, 2000, p. 66). Para ele, a literatura de testemunho tem em foco a sua construção a partir do presente. São as problemáticas enfrentadas no agora que impulsionam os sujeitos a narrar o seu passado traumático. Necessidade que vem por este passado não ter sido superado, ainda ser presente. "O sobrevivente não vive com memórias de um passado que ficou para trás, mas sim com acontecimentos que continuam no presente" (FERNANDES, 2008. p. $37)$.

O trauma histórico, da tortura, da opressão, da censura, do exílio e da morte; ou ainda, da acusação, da culpa e da incompreensão, teria conservado em aberto a configuração simbólica das diferentes agressões sofridas, ao mesmo tempo em que clamaria por sua superação pelo testemunho entendido como superstes, "aquele que viu e subsiste além de", aquele que "se mantém no fato" e como tersti, "terceiro", aquele que ouve (SELIGMANN-SILVA, 2005, p. 80). É nesse sentido que entendemos cumprir seu papel a obra de Frei Betto: documento, testemunho, denúncia, mediação, publicização, justiça. 


\section{A obra Batismo de Sangue: superstes e tersti}

Do final dos anos 1970 ao começo da década de 1980 o Brasil foi marcado por um processo conflituoso e doloroso - porém necessário à democracia - de sua história. O país estava vivendo o contexto da chamada "abertura política", iniciada oficialmente pelo governo do general Ernesto Geisel (1974-1979). A Lei da Anistia, em 1979, consolidava a posição de mediação tomada pelo Estado, nivelando direitos de torturados e torturadores e declarando o "perdão oficial", obrigatório, que condenou a todos ao silenciamento. $O$ debate sobre $o$ reconhecimento, $\mathrm{o}$ julgamento $\mathrm{e}$ as reparações aos crimes cometidos nos porões da ditadura era dado por encerrado, mesmo antes de ter início, deixando feridas abertas em nossa sociedade.

Obras testemunhais lançadas a partir da década de 1980 foram importantes ferramentas, de cunho político, contra a memória oficial que se hegemonizava e o esquecimento imposto. Ouvidos e olhos precisavam ser abertos e estar atentos para que as memórias das vítimas do regime confrontassem seus perpetradores, e a literatura procurou cumprir esse papel de forma exemplar. Enquanto documentos oficiais eram arquivados e a violação aos direitos humanos era ignorada, muitos escritores percorriam o caminho do registro de suas experiências ou de outros, para não calar. Entre muitos títulos, figuravam O que é isso companheiro (1979), de Fernando Gabeira; Feliz Ano Velho (1982); de Marcelo Rubens Paiva; Brasil Nunca Mais (1985), organizado por Dom Paulo Arns e, mais recentemente dentre tantos outros, Memórias do Esquecimento (1999), de Flávio Tavares, todos de caráter testemunhal.

Lançado em 1982, Batismo de Sangue relata a prisão de um grupo de religiosos dominicanos que apoiaram o combate armado ao regime militar. No livro, o autor tece a relação dos dominicanos com o líder da guerrilha urbana, Carlos Marighella, "uma das pessoas mais procuradas pelo aparelho militar instalado no país após março de 1964" (BETTO, 2006, p. 35), por meio da colaboração dos religiosos para o "esquema de fronteiras" da ALN (Ação Libertadora Nacional). O "esquema de fronteiras" era um mecanismo organizado pelos frades, através do qual retiravam perseguidos políticos do país, muitos dos quais haviam ajudado a esconder em seus seminários. Este Revista Eletrônica Literatura e Autoritarismo: Narrativa Testemunhal e Relações Históricas - ISSN 1679-849X |71| http://cascavel.ufsm.br/revistas/ojs-2.2.2/index.php/LA/index 
auxílio, segundo o autor, não era articulado em células, nem chegava a ser um trabalho sistemático, pois não tinha um cunho político de organização. A proteção era dada a diversos indivíduos de qualquer partido ou agrupamento que fizesse oposição ao regime e que corresse perigo de prisão:

\begin{abstract}
Esse apoio caracterizava-se, sobretudo, por guardá-los em locais seguros, transportá-los de uma cidade a outra e tranquilizar suas famílias. Dentro de nossas possibilidades e condição de religiosos, ajudávamos pessoas sob risco de prisão, tortura e morte. (BETTO, 2006, p. 81)
\end{abstract}

O escritor revela, acima de tudo, a condição religiosa da missão de seus companheiros, enquanto defensores dos perseguidos, como assim fora Cristo e também por orientação do Papa João XXIII que, partir do Concilio Vaticano II, em 1962, pregava a aproximação da Igreja com os excluídos e injustiçados. Ou seja, as ações dos dominicanos se justificavam por uma prática mais humanitária e conciliatória da instituição, num mundo marcado por conflitos. 0 grupo formado, além do escritor, por Tito de Alencar Lima, Oswaldo Rezende, Fernando de Brito e Ivo Lesbaupin (hoje ex-dominicano), foi preso entre 2 e 9 de novembro de 1969 e, com exceção de Frei Betto, foi submetido aos órgãos de repressão e tortura, a fim de obter informações sobre o líder revolucionário, Carlos Marighella. Supostamente, a partir de dados arrancados mediante sevícia dos religiosos, os órgãos de segurança montaram uma emboscada e assassinaram o líder da ALN, na noite de 4 de novembro de 1969.

Frei Tito foi solto em janeiro de 1971, pois seu nome compunha a lista de prisioneiros políticos que deveriam ser libertados em troca do embaixador suíço, Giovanni Bücher, sequestrado pelo comando da VPR (Vanguarda Popular Revolucionária). Em 1974, aos 28 anos, em decorrência das torturas sofridas em São Paulo, frei Tito se suicidou, passagem que Christo enfatiza, demonstrando a via crucis de seu amigo, enlouquecido pela racionalidade da máquina de tortura do Estado brasileiro. Os demais dominicanos foram soltos do Presídio Tiradentes em 1973.

Frei Betto levou cerca de dez anos para escrever Batismo de Sangue. Nesse tempo o religioso colheu diversas entrevistas, consultou documentos, revisitou os locais narrados para recompor a triste desventura que os marcou. Sobre a demora na reelaboração do passado traumático Dori Laub () afirma 
que o tempo do testemunho é resultado da impossibilidade do indivíduo narrar diretamente 0 evento. $O$ intervalo histórico entre o evento traumático e 0 posterior testemunho demonstra que o sobrevivente, muitas vezes, não acredita que o mundo está pronto para sua narrativa. No caso de Batismo de Sangue, a distância temporal foi preenchida pela pesquisa do religioso, procurando legitimar e assimilar o que ele próprio estava se dispondo a contar. O testemunho, assim, foi construído a partir das expectativas e das angústias do sobrevivente após o evento traumático.

$\mathrm{Na}$ introdução do livro, o autor também afirma que o processo de escrever o livro começou desde que saiu do Presídio Tiradentes, após ter conhecido tantas histórias e compartilhado sua experiência de cárcere com outras pessoas, submetidas, inúmeras vezes, ao sofrimento, à humilhação e à morte. Assim, como afirma Fabrício Fernandes, o autor pareceu ser motivado a narrar episódios traumáticos de seu passado a partir de um dever ético e moral, a noção de obrigação social do sobrevivente:

Quando se estuda o relato de fatos encravados em um determinado período político, especialmente um período de autoritarismo, a escrita do passado busca fornecer subsídios às mais aprofundadas compreensões históricas e registrar a interpretação a partir de um ponto. (FERNANDES, 2008, p. 103)

Em outras palavras, livros memorialísticos não são escritos por questões como nostalgia ou simples registro factual. $O$ que move os autores, como Betto, sobreviventes de catástrofes de qualquer magnitude, seja como vítimas (superstes) ou como observadores dos crimes (tersti) é a convicção de que seu testemunho tem uma função de contrapor versões oficiais, denunciando os acontecimentos repressivos, violentos, que inúmeras vezes são negados pelos então detentores do poder estatal ou por apoiadores civis do regime. Assim, uma das funções históricas da literatura de testemunho é fomentar o debate para que as vítimas de barbáries possam "reconciliar de uma vez com seu passado e com a sociedade, para que esse passado seja finalmente uma página virada" (BERTONHA, 2012, p. 11).

O contexto de produção de Batismo de Sangue propicia identificar esta característica da literatura testemunhal. O constante silenciamento promovido a 
partir do final da ditadura, em relação ao "desaparecimento" e à morte de inúmeros presos e presas; a não retração dos torturadores; a não reparação, simbólica e material, dos abusos cometidos durante o regime; o calvário e o suicídio de frei Tito, foram prováveis indignações que motivaram Frei Betto a escrever o que se passou durante a prisão dos dominicanos nos porões da repressão. Nesse sentido, "a memória do trauma é sempre uma busca pelo compromisso entre o trabalho da memória individual e outro construído pela sociedade" (SELIGMANN-SILVA, 2008, p. 67).

Batismo de Sangue é produto de um processo de experiências de um indivíduo, também resultado de interações sociais. Ali a memória narrada pelo autor - não apenas sua, mas fazendo jus a outros que não puderam contá-la não trata de um banco depositário dos fatos, mas a um processo de constante significação. Como afirma Alessandro Portelli (1996), as mudanças que por ventura ocorrem no discurso memorialístico são significativas por representar a busca do sobrevivente em dar um sentido ao seu passado.

A literatura testemunhal existe no seu contexto de denúncia, contrahistória, de busca por justiça. Segundo Seligmann-Silva, uma das principais características da vítima de uma calamidade é que a tarefa de testemunhar é intransferível. $\mathrm{O}$ ato de narrar, testemunhar, ameniza 0 sofrimento do sobrevivente, sendo fruto da dor individual, mas também coletiva, da reivindicação de justiça histórica a um determinado grupo. Sendo produtos do homem no tempo, as narrativas testemunhais permitem aos historiadores compreender a História como um acontecimento vivo repleto de complexidades e subjetividades.

O homem é um ser que modifica seu meio a partir das experiências vividas; aprender a partir da dor do outro, por meio da literatura, é uma didática além da simples explicação. É partilhar, é tornar o outro - leitor ou ouvinte também uma testemunha. Testemunhos permitem-nos significar e ver que a história sempre é feita de possibilidades, colocando todos na mesma condição enquanto ucronia e esperança de que os vestígios destas perpetrações e desumanizações sejam varridos por esta "literatura feita de lágrimas". 


\section{A Igreja representada por Frei Betto no livro Batismo de Sangue}

A posição de enfrentamento ao regime autoritário, por parte de setores da Igreja no Brasil foi pouco retratada na literatura, no cinema e também pela historiografia, até pelo menos os anos 1990. Assiste-se hoje a um maior volume de produção, de caráter acadêmico ou não, de pesquisas e trabalhos que procuram representar e refletir sobre o período de censura, exílio, prisões e assassinatos, expondo cada vez mais o passado sombrio e convocando a sociedade a enfrentá-lo. Principalmente no contexto de formação e atuação da Comissão Nacional da Verdade (CNV), pela presidenta Dilma Rousseff, em 2012.

No contexto em que Frei Betto escreveu, no entanto, pouco ainda havia sido retratado e discutido, pois a ordem era esquecer. Isso não apenas dificultou a narrativa relativa às histórias de membros de grupos armados, como também jogou para segundo plano atuações menos evidentes, como a dos frades. Daí a importância de sua obra, demonstrando que os frades dominicanos passavam por um processo de aproximação com os grupos de enfrentamento da ditadura e que muito contribuíram para salvar vidas e realizar táticas de luta. Apesar da cúpula da Igreja ter apoiado o golpe de 1964, os anos de 1967 e 1968 foram fundamentais para a leitura que muitos religiosos fizeram do cenário político e econômico do país, moldando suas futuras ações de intervenção em oposição e resistência ao governo ditatorial.

Segundo Frei Betto, o ano de 1967 marcou uma grande mudança no modo como os dominicanos viviam. A Igreja Católica passava por um processo de secularização, ou seja, uma desclericalização de seus agentes: "A moda consistia em dependurar a batina, usada apenas em ofícios religiosos, trocar o seminário pela universidade e o convento por pequenas comunidades" (BETTO, 2006, p. 70). Os novos vocacionados dominicanos, nessa época, eram enviados à França para completar seus estudos em filosofia e teologia. Ao retornarem, estavam cheios de ideias progressistas, encontrando em dom Helder Câmara e na Ação Católica um norte para atuação. Os dominicanos "agora se envolviam com o mundo operário e o movimento estudantil, interessados em formar lideranças leigas impregnadas de valores evangélicos" (BETTO, 2006, p. 70). 
A instituição vinha buscando uma nova relação com o mundo moderno, marcado por catástrofes e opressões das mais diversas formas. O debate sobre o posicionamento da instituição religiosa e de seus agentes pastorais aconteceu entre 1962 e 1965, no Concílio Vaticano II, sob a liderança dos Papas João XXIII e Paulo VI. A Igreja tentava transformar a sua relação com o mundo político, colocando a justiça social em primeiro plano, e também a defesa dos direitos humanos. Era hora de encontrar novas relações entre a fé e o político-social.

Após o Concílio Vaticano II, em março de 1967, o papa Paulo VI escreveu a Carta Encíclica Populorum Progressio, documento em que retomava a importância da conscientização e da participação da Igreja nas questões sociais dos povos. O texto denunciava o agravamento provocado pelo desequilíbrio entre países ricos; criticando o neocolonialismo e afirmando o direito de todos os grupos sociais ao bem-estar. Esta escrita foi uma das encíclicas mais importantes da história da Igreja Católica, ainda que tenha suscitado críticas severas entre os mais conservadores. Ali, lembra Frei Betto em sua obra, era reconhecida como legitima a luta armada, ao abordar os danos causados por revoluções, em casos de "tirania evidente e prolongada que ameace gravemente os direitos fundamentais da pessoa e prejudique perigosamente o bem comum do país" (BETTO, 2006, p. 71).

Apesar desse quadro vivido pela Igreja Católica no começo da década de 1960, os bispos brasileiros apoiaram o regime militar. Segundo eles, a crença ateísta, que era consequência da ameaça comunista, deveria ser derrotada. A "Marcha da Família com Deus pela Liberdade", alicerce de setores conservadores ao movimento militar, demonstrou a proximidade da instituição religiosa com as elites que estavam no poder. Houve também um manifesto assinado por 26 bispos que agradeciam os militares por "salvarem o país". No documentário Tempo de Resistência (2003), de Andre Ristum, o Arcebispo Dom Angélico Bernardino diz que grande parte da Igreja bateu palmas para 0 golpe militar, também chamada de "revolução" pelos golpistas:

No primeiro momento, foi quase que de aprovação, não unânime, mas a maioria. Num segundo momento, ela tomou consciência de que nós não estávamos numa revolução, que iria trazer melhores condições de vida para o nosso povo. Mas 
realmente era um golpe militar a serviço dos interesses do capital desalmado. E ai então a Igreja foi devagar, mas firmemente, tomando consciência; e mais se posicionando contra o golpe militar. (RISTUM, 2003)

Um dos poucos religiosos da cúpula católica, lembra Frei Betto que Dom Helder Câmara foi contrário ao regime militar desde o início. Como ele, um grupo específico, no caso os frades da ordem dominicana, serviu de apoio à guerrilha armada, protegendo possíveis perseguidos e sustentando suas ações na Carta Encíclica Populorum Progressio.

Além do processo de "humanização" da Igreja, o autor apresenta 1968 como um ano de forte crise política e social enfrentada pelos brasileiros. Frei Betto pontua que os trabalhadores sofriam com o arrocho salarial e com a oposição burguesa que havia se fortalecido ao se ancorar nas forças militares; em contrapartida, as lideranças civis estavam sendo marginalizadas, pois, por mais que setores conservadores da sociedade houvessem apoiado o golpe, a política econômica do governo era uma ameaça para os grupos que visavam deter o controle do Estado. Pequenas e médias empresas faliram, enquanto a aliança entre multinacionais e o empresariado brasileiro se fortalecia.

A obra também apresenta o cenário envolvendo a luta dos estudantes, muitos deles voltados para melhores condições nas universidades, envolvidos em confrontos como quando da morte do estudante Edson Luís ou a passeata dos cem mil, e também seduzidos pela luta armada, que ganhava cada vez mais força, a partir deste ano. Sobretudo os estudantes eram vítimas da repressão do aparelho estatal, por comporem um dos setores mais combativos do país. "Estudantes, artistas e intelectuais promoviam passeatas e atos públicos, divulgavam manifestos, enfrentavam a polícia, improvisando barricadas e incendiando viaturas" (BETTO, 2006, p. 73).

De acordo com o religioso, os secundaristas e universitários passaram por um processo em que o enfrentamento tornou-se mais direto e incisivo. Grêmios e diretórios acadêmicos transformaram-se em organizações de esquerda. Alguns desenvolveram trabalho de base em fábricas, grêmios e igrejas, fazendo apenas do debate de ideias sua forma de luta. Porém, Frei Betto afirma que outros acreditavam que o único caminho eficaz para combater o regime opressor era a ação armada. 
O futuro parecia estar logo ali, à mão. Contudo, predominava o idealismo, a convicção ideológica de que o Brasil só poderia libertar-se da ditadura e da exploração capitalista mediante a única forma de luta possível frente à supressão dos espaços democráticos: o recurso às armas. (BETTO, 2006, p. 72)

Foi nesse efervescente contexto que, segundo o autor, os jovens dominicanos aproximaram-se, de forma cada vez mais acirrada, das organizações de esquerda e envolveram-se com a guerrilha, em especial à Ação Libertadora Nacional (ALN), liderada por Carlos Marighella. Por serem estudantes da USP, a maioria deles começou a participar da política estudantil, comungando "os impasses e as opções de uma expressiva parcela de nossa geração universitária" (BETTO, 2006, p. 78).

O nome de Marighella emergia neste complexo momento político como sinal de esperança para muitas pessoas, dentre elas os frades dominicanos. A ALN era um dos principais agrupamentos de enfrentamento à ditadura civilmilitar "Conhecida por suas sucessivas ações armadas, e por ser comandada pelo mais notório revolucionário brasileiro, a ALN reuniu, sobretudo, jovens oriundos da pequena burguesia, despertados politicamente pelo movimento estudantil" (BETTO, 2006, p. 59).

A figura do líder revolucionário é uma presença muito forte nos relatos de Frei Betto. A primeira parte do livro é dedicada a ele, intitulada "Carlos, o itinerário". Nela, o frade descreve parte da vida do guerrilheiro baiano e também sua trajetória política, na resistência a regimes autoritários desde o governo de Getúlio Vargas, quando também teria sido preso. Na obra, o autor busca personificar nele os ideais que moveram tanto os jovens da ALN quanto os dominicanos:

Ainda estudante, Marighella ingressou no PCB (Partido Comunista do Brasil). Destacou-se logo como um dos mais combativos militantes baianos, dotado de excepcional capacidade de trabalho e admirável coragem pessoal. Costumava dizer que não tinha tempo para ter medo. (BETTO, 2006, p. 21)

Para apresentar a biografia descrita neste trecho da obra, Libâneo Christo faz menção a reportagens e pesquisas realizadas, além de entrevistas 
com pessoas que eram próximas a Marighella. Assim, mais do que simplesmente querer narrar fatos, a memória procura marcar a ideia de que 0 personagem político nunca deixou de lado os ideais socialistas que recebera de berço, sendo fiel aos seus ideais até o final. Ao ingressar na faculdade entrou para o PCB, e a partir daí começou sua trajetória na linha revolucionária, optando pela chamada "ação direta". Preso mais de uma vez, foi torturado pelos órgãos de repressão desde a década de 1930, encarnando o herói revolucionário, disposto a morrer pela causa:

A dor fez-se companheira em seu silêncio. (...) Esse o preço da fidelidade a uma causa, salário de morte e amor que não se paga com o simples querer. A resistência humana tem limites nem sempre conhecidos. Ao encarar em sua vida os ideais pelos quais lutava, Marighella conseguiu que o limite de sua resistência chegasse à fronteira em que a morte recebe 0 sacrifício como dom. (BETTO, 2006, p. 27-28)

No que se refere ao processo de aproximação dos dominicanos da pauta progressista dos movimentos de esquerda, Marighella também acreditava que a Igreja era um aliado para a revolução brasileira. Em seu texto, A Crise Brasileira, ao referir-se à unidade e luta com a burguesia em frente única, o intelectual e guerrilheiro afirma que "um dado valioso para essa unidade - tendo em vista atrair o centro - é a aliança com os católicos e, em particular, com a esquerda católica" (MARIGHELLA apud BETTO, 2006, p. 39).

De acordo com Frei Betto, ao estreitar a aproximação com os dominicanos e montar o esquema de fronteiras, Marighella identificava os religiosos como ponta de lança para a implementação das bases da guerrilha, demonstrando ter neles confiança. A narrativa deixa clara a postura de outra Igreja, ancorada no compromisso revolucionário, representado pelo espírito cristão de solidariedade:

O papel de vocês, de apoio à guerrilha, não poderia nunca desembocar numa ajuda tão efetiva na área de apoio logístico, e sim obter informações e fazer levantamento da região do Araguaia. $E$ isso já foi feito. Restaria preparar o povo através da pregação de vocês nas cidades da região e, principalmente, no interior. Esse desvio de estratégia me obriga a tomar uma decisão. A partir de agora vocês ficarão ligados ao Comando Nacional e diretamente à minha pessoa. (BETTO, 2006, p. 232) 
Apesar desta posição tomada por Marighella e do papel que desempenharam no "esquema de fronteiras", no momento histórico em que Frei Betto escreveu Batismo de Sangue os dominicanos eram tidos como traidores por alguns militantes de esquerda. Jacob Gorender, em seu livro Combate nas trevas, publicado em 1987, afirmava que quando esteve preso era generalizada a convicção de que a morte do líder da ALN era responsabilidade dos freis Fernando e Ivo. Ele também criticaria a obra do religioso, afirmando que a mesma era composta de "invencionices":

O meu silêncio de historiador significaria conivência com a versão divulgada por Frei Betto, em curso no Brasil e no exterior. Silêncio inadmissível diante do compromisso que o historiador tem com a verdade. [...] Frei Betto preferiu a meia verdade, o que é igual à meia falsidade. Sua versão reconhece que, sob tortura, Fernando e Yves (hoje, ex-frade) denunciaram o dispositivo de ligação com o líder da ALN. (GORENDER, 1998, p. 190)

Nas últimas edições de Batismo de Sangue, já nos anos 2000, consta a resposta de Frei Betto às acusações de Jacob Gorender, revelando a literatura como campo de disputa entre memórias que se alargaram no tempo histórico. Segundo o religioso, Gorender não esclarecia como a repressão soube do apoio logístico dominicano. Afirma, também, que não foram os frades que procuraram a polícia, procurando desconstruir a versão de que foram traidores. O frade procura deixar claro que foi a barbaridade da tortura, como acontecera com tantos outros prisioneiros políticos, que teria levado à delação, aqui vista como fraqueza e não como crime ético contra a revolução. O dominicano também critica o autor de Combate nas Trevas por desprezar duas fontes vivas sobre os acontecimentos, deixando de observar, com isso, a possibilidade da "verdade":

Gorender nunca demonstrou o menor interesse em entrevistar Ivo e Fernando, mas teve o cuidado de ouvir a versão de Paulo de Tarso Venceslau, como se o visceral anticlericalismo incutido em alguns comunistas brasileiros tivesse ainda o peso capaz de prejudicar a objetividade de quem pretende encarar a história pelo método científico. O compromisso com a verdade deve estar acima de preconceitos. (BETTO, 2006, p. 257) 
Aqui podemos perceber a luta entre diferentes conceitos de verdade, sendo a testemunhal defendida por Frei Betto como de fundamental importância para se "escovar a história a contrapelo", não apenas no sentido de desvelar a versão dos opressores e vencedores, mas para fazer justiça aos frades que tiveram sua história silenciada ou desprezada pela própria esquerda armada, segundo ele.

A versão do religioso procura romper com certo imaginário que persistia na década de 1980, em torno da tentativa de valorizar a luta e o sofrimento dos guerrilheiros, silenciados pela Lei da Anistia, em detrimento ainda de outros setores não tão visíveis, como os freis dominicanos, para ele incompreendidos e injustiçados. Não se quer afirmar, concordando com Fabrício Fernandes (2008), que o testemunho de um indivíduo corresponda à memória construída coletivamente, nem que, ao contrário, ele tenha teor mais verdadeiro do que outro. No caso de Batismo de Sangue, o livro dialoga com a memória de um determinado grupo de indivíduos sobre o período da ditadura civil-militar e procura se posicionar diante da história, por meio da memória do autor, representativa de um coletivo no jogo de forças.

Em A Escrita da Dor, Fabrício Fernandes aponta que a responsabilidade de ser sobrevivente de uma catástrofe de natureza coletiva é muito grande, o que pode gerar uma pressão esmagadora sobre ele quanto ao dever de contar e falar em nome dos que pereceram:

Se o evento violento for de natureza coletiva, a sobrevivência é capaz de gerar respostas as mais diversas: surge algo como compromisso com aqueles que pereceram e a necessidade imperiosa de encontrar uma justificativa pelo "beneficio" imerecido. (FERNANDES, 2008, p. 46)

A sobrevivência em casos de grandes catástrofes pode gerar no sujeito uma ideia de beneficio imerecido. Frei Betto foi o único dos frades dominicanos que não passou pela tortura enquanto esteve preso e também não morreu, mas viveu a experiência da dor, em meio a tantos que não sobreviveram, como seu companheiro Frei Tito. Isto se tornou responsável pelo compromisso de narrar, principalmente os episódios do ano de 1969, quando a esquerda sofreu grande derrota, sendo desmantelada pelos órgãos de repressão, de forma que as pessoas de seu tempo pudessem tomar conhecimento e reconhecer a Revista Eletrônica Literatura e Autoritarismo: Narrativa Testemunhal e Relações Históricas - ISSN 1679-849X |81| http://cascavel.ufsm.br/revistas/ojs-2.2.2/index.php/LA/index 
necessidade de lembrar sempre da dor dos outros: "O sobrevivente não vive com memórias de um passado que ficou para trás, mas sim com acontecimentos que continuam no presente" (FERNANDES, 2008, p. 37).

Ao escrever a forma com a qual Marighella, os padres e Frei Tito, em especial, foram barbaramente torturados e/ou assassinados, Frei Betto usa de formas poéticas e metáforas para descrever as cenas, indizíveis pela linguagem ordinária. Segundo o autor, coletar estas informações e reescrevêlas foram experiências dolorosas, mas, como afirma Seligmann-Silva, trata-se de uma questão também de sobrevivência, um compromisso ético com a história, entendida como vida, experiência, tempo aberto. Para realizar a possibilidade de narrar, a literatura lança mão de dois caminhos: o primeiro é a imaginação, o segundo é a utilização de recursos metafóricos para superar a dificuldade em completar a distância que há entre linguagem e a experiência em si. Enfim, diante de realidade tão cruel e impactante para os indivíduos, a literatura testemunhal utiliza recursos capazes de discutir as subjetividades, que documentos tradicionais não dão conta de demonstrar.

O papel da literatura no contexto dos traumas e testemunhos é o de justamente jogar com o simbólico: "A imaginação é chamada como arma que deve vir em auxílio do simbólico para enfrentar o buraco negro do real do trauma" (SELLIGMANN-SILVA, 2008, p. 70). Ela permite encenar a criação do real, representar a batalha por justiça histórica e cicatrizar feridas que não se fecham, não se curam pelo silenciamento reproduzido em vários espaços.

Segundo Fabrício Fernandes (2008), o conhecimento que produzimos sobre as atrocidades é sempre distanciado, parcial, se não for permeado pela visão da vítima do mesmo. As narrativas e literaturas de testemunho são meios pelos quais os horrores de eventos traumáticos são transmitidos. Mas não são simplesmente produtos criados para veicular informação. São escritos para transmitir experiências. Além de transmiti-las, Batismo de Sangue denuncia as atrocidades que aconteciam nos porões da ditadura e também as consequências permanentes na vida coletiva do país. Em umas das passagens do livro, o autor comenta sobre a natureza do torturador e traz à tona uma leitura sobre a figura do perpetrador, que imbuído da "ética" que estigmatizava seus opositores como terroristas, acostumava-se aos "respingos de sangue" dos presos em suas fardas:

|82| Revista Eletrônica Literatura e Autoritarismo, oo 27 - janeiro a junho de 2016 - ISSN 1679-849X http://cascavel.ufsm.br/revistas/ojs-2.2.2/index.php/LA/index 
Estranho universo o da consciência humana! Aquele mesmo pai de família, atribulado por trair a esposa, era um torturador notório, que se comprazia em enfiar um tubo de borracha na vagina de presas políticas. As ditaduras geram monstruosidades À sua imagem e semelhança. Para o poder absoluto, o inimigo não tem sequer direitos relativos. Aprendese a matar como o açougueiro em seu trabalho. A diferença é que esse último lida com animais, que alimentavam vidas humanas, enquanto o torturador sacrifica vidas à idolatria do poder. (BETTO, 2006, p. 206)

A denúncia da violência cometida pelo Estado também é representada pelo capítulo dedicado a frei Tito de Alencar. Na última parte da obra memorialística, o autor descreve como foram os últimos momentos vividos pelo frade. Christo "reconstrói" falas de frei Tito sobre as torturas sofridas na OBAN (Operação Bandeirantes), na década de 1970, seus temores e neuroses como imaginar o delegado e torturador Fleury em todos os cantos do mosteiro a persegui-lo e ameaçá-lo - até seu suicídio. Na obra, o autor utiliza da frase deixada por Frei Tito, como forma de dizer por ele e tentar traduzir ao leitor a dor da tortura: "Melhor morrer do que perder a vida".

Segundo Frei Betto, na OBAN, os militares buscavam derrubar a resistência dos interrogados. O medo de continuar sofrendo era mais perverso que a dor em si. Era infundido na cabeça dos militares que ninguém confessaria seu crime sem ser forçado. Logo, a tortura seria o único encaminhamento para fazer os presos falarem. $\mathrm{O}$ escritor escreve em primeira pessoa quando se trata da posição de Tito:

De estômago vazio, fui para a sala de interrogatórios. Um capitão, cercado por sua equipe, voltou às mesmas perguntas: "Vai ter que falar senão só sai morto daqui"!, gritou. Logo vi que não era apenas uma ameaça, era quase uma certeza. Sentaram-me na cadeira-do-dragão, com chapas metálicas e fios, descarregaram choques nas mãos, nos pés, nos ouvidos e na cabeça. Dois fios foram amarrados em minhas mãos, e um na orelha esquerda. A cada descarga, eu estremecia todo, como se o organismo fosse se decompor. (BETTO, 2006, p. 372)

Como dito anteriormente, a maneira como a qual as narrativas de testemunhos são escritas, reflete a dificuldade da testemunha em conseguir expressar em totalidade o seu trauma. Além de descrever em primeira pessoa, 
como assumindo a dor do outro e por ela quase se responsabilizando, Frei Betto também comenta que em Tito a tortura não foi apenas mais um método para obter informações, mas que "foi sangrado na carne até que a dor e o pânico atingissem o âmago de sua alma" (BETTO, 2006. p. 413). Denuncia: o que houve com frei Tito não foi exceção, foi a regra:

De modo exemplar, Frei Tito encarnou todos os horrores do regime militar brasileiro. Este é, para sempre, um cadáver insepulto. Seu testemunho sobreviverá À noite que nos abate, aos tempos que nos obrigam a sonhar, à historiografia oficial que insiste em ignorá-lo. (BETTO, 2006, p. 413)

\section{Considerações finais}

Obras de literatura testemunhal como Batismo de Sangue são ferramentas fundamentais para o ofício dos historiadores e historiadoras. A literatura de testemunho só existe pelo seu contexto de contra-história, de denúncia e da busca por justiça.

O silêncio artístico e historiográfico corrobora para que a memória oficial, a memória dos perpetradores, continue sendo reproduzida. É não dar paz a todos e todas que pereceram nas celas dos órgãos de repressão, não dar consolo aos familiares e amigos, também vítimas da ditadura civil-militar. É não garantir justiça e não produzir um conhecimento histórico que tenha ressonância com a sociedade.

Quando Frei Betto escreveu, a historiografia e a sociedade civil, em geral, ainda ignoravam o martírio de muitos e muitas que pereceram sob a violência do regime autoritário. Apesar do crescimento no número de produções que expõem cada vez mais as feridas e chamam para a reflexão; apesar da existência da Comissão da Verdade e da ampliação dos debates em torno da transição democrática, ainda Batismo de Sangue continua a ser republicada, em novas versões que promovem o diálogo com a sociedade em torno da violação dos direitos humanos e dos esquecimentos forçados. Sempre atual, a obra denuncia este silêncio que muitas vezes ainda incomoda, nos levando a pensar até que ponto estamos produzindo um conhecimento que realmente abranja as necessidades e demandas de nossa sociedade. É 
necessário que se rompam preconceitos e a apatia para que ocorra uma superação deste passado traumático.

A literatura de testemunho assim como a história são ferramentas para enfrentar a perpetuação das feridas de um passado traumático. Permite-nos, por meio de linhas marcadas por intensas lágrimas, dar nome aos mortos e "desaparecidos" e fazer justiça àqueles retirados de sua condição de humano. Não para criar heróis, mas reconhecer pessoas que, com suas experiências e relatos, constroem a história de luta contra opressões e formas de autoritarismo. O testemunho cumpre o papel de justiça histórica, dando forma a uma literatura de reflexão, denúncia e reparação, não para vitimizar e lamentar apenas, mas para reconhecer e fortalecer formas de luta pela construção democrática.

A literatura testemunhal é também homenagem aos que pereceram durante a ditadura civil-militar. É o que acreditamos que o autor tenha buscado realizar, por meio de seu livro: dar nomes, narrar as trajetórias, as arbitrariedades, a violência e a ausência de vida. Procurou, através de sua narrativa, não apenas contar a história, mas fazer justiça aos esquecidos, no caso os frades dominicanos, torturados, assassinados e acusados de delação e traição do movimento guerrilheiro ligado a Carlos Marighella.

Uma obra como Batismo de Sangue trata mais do que representação da ditadura militar. Ela é um diálogo, quer ser aprendizado e projeção de futuro, na perspectiva de que a sociedade possa ter acesso ao conhecimento não dito e silenciado pelo regime autoritário. Frei Betto é uma versão sob os olhos do testemunho, discutindo o acontecido, mas revelando planos e desejos não realizados, possibilidades que não vingaram pela violência do Estado. Acontecimentos que a simples anistia decretada pelo Estado não é capaz de fazer esquecer. Nesse sentido, a história e a literatura se embrenham no labirinto da memória, construído a partir de angústias do presente, e entrelaçam fios que não são os de Ariadne, porque confusos, trançados, e amplos, mas necessários a uma sociedade que precisa enfrentar seu passado para construir outros futuros possíveis. 


\section{Referências}

BARROS, José A. Literatura e História: novas relações para novos tempos. Contemporâneos. n. 6, maio/out, 2010.

BENJAMIN, Walter. Sobre o conceito de História. Obras escolhidas. Vol. 1. Magia e técnica, arte e política. Ensaios sobre literatura e história da cultura. São Paulo: Brasiliense, 1993, p. 222-232.

BERTONHA, João F. Problemas e questões da história do tempo presente. Revista Eletrônica Cadernos de História, ano 7, n. ${ }^{\circ}$ 1, junho de 2012.

BETTO, Frei. Batismo de Sangue: guerrilha e morte de Carlos Marighella. Rio de Janeiro: Rocco, 14르 Ed, 1982/2006.

CUYA, Esteban. Justiça de Transição. Acervo, Rio de Janeiro, v. 24, no 1, jan/jun, p. 37-78, 2011.

FERNANDES, Fabrício. A escrita da dor. Doutorado. Campinas: Universidade Estadual de Cmapinas, 2008

GINZBURG, Jaime. Escritas da Violência. São Paulo: 7 Letras, 2012.

GORENDER, Jacob. Combate nas trevas. São Paulo, Ática, 5ª Ed., 1998

PESAVENTO, Sandra Jatahy. História e História Cultural. Belo Horizonte: Autêntica, 2004.

Relação entre História e Literatura e Representação das Identidades Urbanas no Brasil (século XIX e XX). Revista Anos 90, Porto Alegre, n. 4. dezembro de 1995.

PORTELLI, Alessandro. A Filosofia e os Fatos: Narração, interpretação e significado nas memórias e nas fontes orais. Tempo, Rio de Janeiro, vol. $1, \mathrm{n}^{\circ}$. 2, p. 59-72, 1996.

SELIGMANN-SILVA, Marcio. Literatura e trauma. Pro-Posições, vol. 13 n. 3 (39), 2002.

. Narrar o trauma: a questão dos testemunhos de catástrofes históricas. Psicologia. Clínica, Rio de Janeiro, vol. 20 n.1, p.65-82, 2008.

- Testemunho e a política da memória: o tempo depois das catástrofes. Projeto História, São Paulo, 2005. p. 71-98.

TEMPO de resistência. Direção: André Ristum. 2004, 110 minutos. Disponível em < https://www.youtube.com/watch?v=7o8z0L7t6pw>, acessado em 22 de setembro de 2015. 